\title{
コロイダル懸架装置を用いた自動車の快適性に関する評価*
}

\author{
Claudiu Valentin SUCIU*1，飛石 翼 ${ }^{* 2}$
}

\section{Comfortableness Evaluation of an Autovehicle Equipped with Colloidal Suspensions}

\author{
Claudiu Valentin SUCIU ${ }^{* 1}$ and Tsubasa TOBIISHI \\ ${ }^{* 1}$ Fukuoka Institute of Technology, Department of Intelligent Mechanical Engineering \\ 3-30-1 Wajiro-Higashi, Higashi-ku, Fukuoka, 811-0295 Japan
}

\begin{abstract}
Common autovehicle suspensions employ hydro-pneumatic absorbers placed in parallel with compression springs that provide the necessary restoring force. Since the spring can be omitted, compact and lighter design can be achieved by using the recently proposed colloidal suspensions. In this work, frontal and rear colloidal suspensions were designed to replace the classical suspensions, and tests of an autovehicle traveling on normal road with an asphalt step were performed. From the impulse response of tested autovehicle one evaluates its comfortableness, both based on the $K$ factor method and based on the equivalent acceleration recommended by the ISO 2631 standard. Such testing method allows comfortableness evaluation without using an expensive test rig on which the autovehicle is placed over four actuators and excited to simulate the real road conditions. Results obtained are firstly validated in the case of classical suspensions consisted of oil dampers mounted in parallel with compression springs. Then, colloidal dampers with and without attached compression springs were evaluated. Relationship between the travel speed of the autovehicle and the level of vibration perception, as well as the influence on the sickness, concentration and health was obtained for various values of the tire inflation pressure. Ride-comfort decreases at augmentation of the travel speed and the tire inflation pressure. Although the colloidal suspension was found to provide inferior comfortableness than the classical suspension, results obtained are encouraging, since better performances are to be expected by optimal design of the colloidal spring.
\end{abstract}

Key Words : Damping, Damper, Automobile, Comfortability in Riding

\section{1. 緒言}

自動車用コロイダル懸架装置に関する開発と実用化研究の背景を調査すると，フランスの研究者はコロイド溶 液を弾性袋の中に密閉し，このような複数の減衰要素を油圧シリンダ内に入れ，コロイドとオイルを組み合わせ たハイブリッドダンパーを提案した(1)(2).このような自動車用ハイブリッドダンパーの原理, 構成, 減衰特性など について報告された ${ }^{(1)(2)}$ が，車両用サスペンションとしての可能検討がまだ発表されていない．これに対して，日 本の研究者はダンパーのエコ化・単純化・コンパクト化を狙って, コロイド溶液を直接作動シリンダ内に密閉し た構造を提案した ${ }^{(3)}$ (7). このようなコロイダルダンパーの耐久性問題を解決するために，コロイド溶液用容器と フィルタの構造を使用することによって十分な寿命を持つダンパーが得られた ${ }^{(8)(9)}$. また，フィルタの代わりにゴ ム層やダイアフラムを用い，コロイダルダンパーの動特性改善に関する開発研究が発表された。コロイダルダン パーの耐久性実験ではサーモカメラを用いた作動時間経過に対するダンパーの外面温度分布の調査より，ダンパ 一の内部温度と発生熱量が評価された ${ }^{(10)(11)}$. その結果, 油圧ダンパーでは散逸エネルギーの大部分が熱に変換す るのに対して，コロイダルダンパーでは散逸エネルギーの一部分だけが熱に変換することが分かり，コロイダル ダンパーが安定した減衰特性を有することが判明された ${ }^{(10)(11)}$.

* 原稿受付 2011 年 10 月 3 日

*1 正員, 福岡工業大学 工学部 知能機械工学科（广811-0295 福岡県福岡市東区和白東 3-30-1）

*2 学生員, 福岡工業大学 大学院 工学研究科 知能機械工学専攻

E-mail: suciu@fit.ac.jp 
最初に自動車の懸架装置用コロイダルダンパーに関する加振実験や車両の走行実験より，コロイダルアブソー バの減衰特性や自動車の乗心地特性が評価された ${ }^{(12)(15)}$ ，その結果，従来の懸架装置の構造（油圧ダンパーと圧縮 コイルばねからなる並列構造）に対して，コロイダル懸架装置の場合は水が疎水化多孔質シリカゲルから自然的 に脱着することによって復元力が本質的に提供されるので, 圧縮コイルばねを省いて懸架装置の単純化ができた (13) (15). 最近, 自動車メーカも, 車両の懸架装置用コロイダルシリンダに関する静特性, 動特性, 並びに乗心地特 性を調ベ，サスペンションの技術としてコロイダル懸架装置は可能であることが確認された ${ }^{(16)}$.

自動車の快適性を評価する際, 通常は車両の左右前後輪が四つのアクチュエータを持つ高価な加振システムに 支持され，複雑な制御装置による実際の凹凸路面の変位励振を室内でシミュレーションする ${ }^{(17)(18)}$. そして, 測定 された加速度データを用いて ISO 2631 規格 ${ }^{(19)}$ による複雑な解析方法で自動車の快適性を評価する. そこで, 本研 究では安価な実験方法として, アスファルト段差を持つ路面でのコロイダル懸架装置を用いた自動車の走行実験 を行い, 段差を通過した際に発生するインパルス応答より, 単純な評価法では乗心地ファクタ (20), 複雑な評価法 では ISO 2631 規格で定められた合成補正加速度 ${ }^{(19)}$ を計算し, 自動車の快適性を評価する. 車両の懸架装置として, 従来のサスペンション (油圧ダンパーと圧縮コイルばねとの並列構造), 並びに提案のサスペンション (コロイダ ルダンパーと圧縮コイルばねとの有無）とし, 快適性（乗心地ファクタ ${ }^{(20)}$ と合成補正加速度 ${ }^{(19)}$ ) に及ぼす自動車 の走行速度, タイヤの岡性などの影響を調べる. コロイダル懸架装置を用いた車両の乗心地を改善するために, 振動解析に基づいて対策方法を提案する.

\section{2. 自動車の快適性の評価方法}

自動車の快適性の評価方法として, 乗心地ファクタ法で定められた等価加速度 ${ }^{(20)}$, 並びに ISO 2631 の国際的規 格で定められた等価（合成補正）加速度 ${ }^{(19)}$ を評価基準とする.

\section{$2 \cdot 1$ 乗心地ファクタによる自動車の快適性評価}

乗心地ファクタ法では等価加速度 $a_{K}$ を次式で計算する.

$$
a_{K}=20 \sqrt{\sum_{i}\left[\left(G \cdot a_{z}\right)^{2}\right]_{i}}
$$

式(1) で使用した記号 $G$ は人間の受振感特性の伝達関数(「座面で測定された縦方向の加速度データ $a_{z}$ に掛けるフ イルタ」, あるいは「周波数重み」と呼ばれる.）である (図 1 参照). 表 1 は乗心地ファクタ法で定められた自動 車の等価加速度 $a_{K}$ と人間の振動知覚力との関係を示しており, 快適な自動車の場合, 等価加速度值 $a_{K}$ が低くな ることが分かる.

\section{$2 \cdot 2$ ISO 2631 規格による自動車の快適性評価}

ISO 2631 規格で定められた等価加速度（合成補正加速度） $a_{W}$ を次式で計算する.

$$
a_{W}=\sqrt{\sum_{i}\left\{\left(\frac{4}{5} W_{c} a_{x B}\right)^{2}+\left(\frac{1}{2} W_{d} a_{y B}\right)^{2}+\left(\frac{2}{5} W_{d} a_{z B}\right)^{2}+W_{d}^{2}\left(a_{x S}^{2}+a_{y S}^{2}\right)+W_{k}^{2} a_{z S}^{2}+W_{k}^{2}\left[\frac{1}{16}\left(a_{x F}^{2}+a_{y F}^{2}\right)+\left(\frac{2}{5} a_{z F}\right)^{2}\right]\right\}_{i}}
$$

式(2) で使用した記号 $W_{c}, W_{d}, W_{k}$ は, ISO 2631 規格で定められた人間の受振感特性の伝達関数である (図 1 参照). また, 記号 $a_{x B}, a_{x S}, a_{x F} ; a_{y B}, a_{y S}, a_{y F} ; a_{z B}, a_{z S}, a_{z F}$ は, 3 箇所（足支持面（Fの下付）, 座面 ( $S$ の下付), 並びに 背もたれ面 (Bの下付) ）に設置する 3 軸（ $x, y, z$ の下付）の加速度計で測定された加速度データを示す. 表 2 は ISO 2631 規格で定められた自動車の等価（合成補正）加速度 $a_{w}$ と人間の振動知覚力との関係を示しており, 快 適な自動車の場合, 等価加速度值 $a_{K}$ （乗心地ファクタ法）と同様に等価加速度值 $a_{W}$ （ISO 2631 法）が低くなる ことが分かる. 
Table 1 Correlation between the equivalent acceleration $a_{K}$ and the human perception of vibration ( $K$ factor method for ride-comfort evaluation)

\begin{tabular}{|c|c|}
\hline $\begin{array}{c}\text { Equivalent acceleration, } \\
a_{K}\left[\mathrm{~m} / \mathrm{s}^{2}\right]\end{array}$ & Perception level \\
\hline$a_{K}<0.1$ & Imperceptible \\
\hline $0.1 \leq a_{K}<0.4$ & Perceptible \\
\hline $0.4 \leq a_{K}<1.6$ & Agreeable sensation \\
\hline $1.6 \leq a_{K}<6.3$ & Strong perception \\
\hline $6.3 \leq a_{K}<15$ & Very strong perception \\
\hline $15 \leq a_{K}<40$ & Influence on sickness \\
\hline $40 \leq a_{K}<90$ & Influence on concentration \\
\hline$a_{K} \geq 90$ & Influence on health \\
\hline
\end{tabular}

Table 2 Correlation between the equivalent acceleration $a_{W}$ and the human perception of vibration (ISO 2631 method for ride-comfort evaluation)

\begin{tabular}{|c|c|}
\hline $\begin{array}{c}\text { Equivalent acceleration, } \\
a_{W}\left[\mathrm{~m} / \mathrm{s}^{2}\right]\end{array}$ & Perception level \\
\hline$a_{W}<0.315$ & Not uncomfortable \\
\hline $0.315 \leq a_{W} \leq 0.63$ & A little uncomfortable \\
\hline $0.5 \leq a_{W} \leq 1.0$ & Fairly uncomfortable \\
\hline $0.8 \leq a_{W} \leq 1.6$ & Uncomfortable \\
\hline $1.25 \leq a_{W} \leq 2.5$ & Very uncomfortable \\
\hline$a_{W} \geq 2$ & Extremely uncomfortable \\
\hline
\end{tabular}

\section{$2 \cdot 3$ 快適性評価に使用するフィルタの比較}

図 1 に乗心地ファクタ法で使用するフィルタ $G$ と ISO 2631 法で使用するフィルタ $W_{c}, W_{d}, W_{k}$ の周波数依存性を 示す. フィルタ $G$ の場合，有効周波数範囲は $0.1 \sim 100 \mathrm{~Hz}$ であり，4〜 $8 \mathrm{~Hz}$ の周波数範囲では車両の上下振動に関 して伝達ゲインが最大高さ（0.708 程度）を示している.これに対して，フィルタWの場合，有効周波数範囲は $0.1 \sim 400 \mathrm{~Hz}$ であり，振動測定箇所（足支持面，座面，背もたれ面）と振動測定軸（ $x, y, z$ ) によって使用するフ イルタが異なる. 例えば, 車両の上下振動伝達に関して (図 4 では $z$ 軸), 足支持面と座面の振動にはフィルタ $W_{k}$ を掛け, 背もたれ面の振動にはフィルタ $W_{d}$ を掛ける (式(2)参照). フィルタの最大高さとして, $W_{c}$ の最大值 (1.024 程度）が周波数 $3.7 \mathrm{~Hz}$ のとき, $W_{d}$ の最大值（1.013 程度）が周波数 $1.1 \mathrm{~Hz}$ のとき，及び $W_{k}$ の最大值（1.054 程度） が周波数 $6.2 \mathrm{~Hz}$ のときに発生する. 人体の振動応答につながるが，フィルタ $G$ の最大值は 0.708 でるのに対し て, フィルタ $W$ の場合, 最大值が若干に 1 を超えた定義になることが分かる. 自動車の快適性を評価する際, ISO 2631 法で 3 種類のフィルタを用いることで精度の高い評価ができると考えられる.

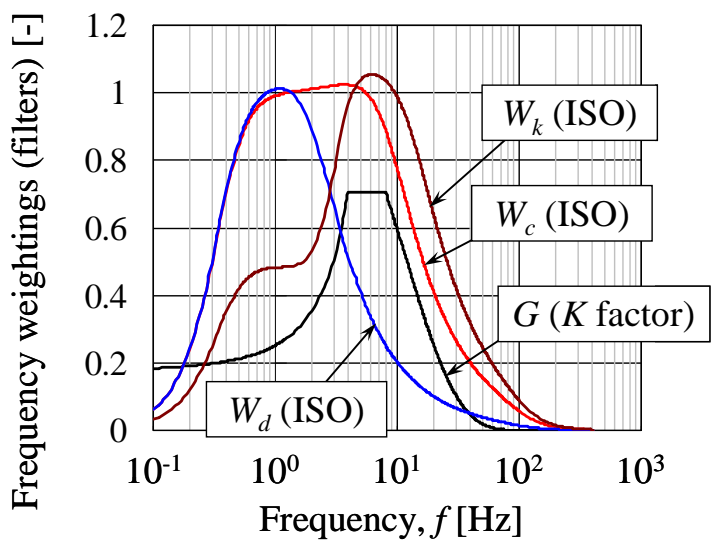

Fig. 1 Variation of the frequency weighting $G$, used by the $K$ factor method for ride-comfort evaluation, and variation of the frequency weightings $W_{c}, W_{d}$ and $W_{k}$, used by the ISO 2631 method for ride-comfort evaluation, versus frequency

\section{3. 自動車に用いた懸架装置}

車両に用いた懸架装置は，従来のサスペンション（油圧ダンパーと圧縮コイルばねとの並列構造），並びに提案 のサスペンション（コロイダルダンパーと圧縮コイルばねとの有無）である（表 3 参照）。表 3 に示すように，前 輪懸架装置において圧縮コイルばねを省いたコロイダル懸架装置の場合，従来のサスペンションに比べ，外径が 
$135 \mathrm{~mm}$ から $55 \mathrm{~mm}$ まで (59\%) 減少し，質量が $5.9 \mathrm{~kg}$ から $4.6 \mathrm{~kg}$ まで（22％）減少する．また，120g のオイル に変わって $30 \mathrm{~g}$ のコロイド溶液（シリカゲル量 : $8 \mathrm{~g}$, 水量 : $22 \mathrm{~g}$ ) を使用する. 同様に, 後輪懸架装置において 圧縮コイルばねを省いたコロイダル懸架装置の場合，従来のサスペンションに比ベ，外径が $105 \mathrm{~mm}$ から $40 \mathrm{~mm}$ まで（62％）減少し，質量が $2.8 \mathrm{~kg}$ から $1.9 \mathrm{~kg}$ まで（32％）減少する．また，80g のオイルに変わって 20gのコ ロイド溶液（シリカゲル量 : $5 \mathrm{~g}$ ，水量：15 g) を使用する.アブソーバと圧縮コイルばねからなる並列構造を用 いた車両用懸架装置の 2 自由度振動モデルを図 2 に示す.このような振動モデルに関係している質量, ばね定数, 及び減衰係数を表 4 に示す. 圧縮コイルばねを省いた提案のコロイダル懸架装置の場合は $k_{C S}=0$ とする.また， 油圧ダンパーのばね定数は $k_{O D} \cong 0$ とする. 表 5 に空気圧力とタイヤのばね定数との関係を示す.

Table 3 Types of suspensions evaluated and their characteristics

\begin{tabular}{|c|c|c|c|c|}
\hline \multirow{2}{*}{$\begin{array}{c}\text { Type of suspension } \\
\text { evaluated }\end{array}$} & \multicolumn{2}{|c|}{ Frontal suspension } & \multicolumn{2}{|c|}{ Rear suspension } \\
\hline & Photograph & Characteristics & Photograph & Characteristics \\
\hline $\begin{array}{l}\text { Actual suspension } \\
\text { (Oil damper in } \\
\text { parallel with spring) }\end{array}$ & & $\begin{array}{l}\text { Mass: } 5.9 \mathrm{~kg} \\
\text { Outer dia.: } 135 \mathrm{~mm}\end{array}$ & & $\begin{array}{l}\text { Mass: } 2.8 \mathrm{~kg} \\
\text { Outer dia.: } 105 \mathrm{~mm}\end{array}$ \\
\hline $\begin{array}{l}\text { Proposed suspension } \\
\text { (Colloidal damper in } \\
\text { parallel with spring) }\end{array}$ & & $\begin{array}{l}\text { Mass: } 6.2 \mathrm{~kg} \\
\text { Outer dia.: } 135 \mathrm{~mm}\end{array}$ & & $\begin{array}{l}\text { Mass: } 3.4 \text { kg } \\
\text { Outer dia.: } 105 \mathrm{~mm}\end{array}$ \\
\hline $\begin{array}{c}\text { Proposed suspension } \\
\text { (Colloidal damper } \\
\text { without spring) }\end{array}$ & & $\begin{array}{l}\text { Mass: } 4.6 \mathrm{~kg} \\
\text { Outer dia.: } 55 \mathrm{~mm}\end{array}$ & & $\begin{array}{l}\text { Mass: } 1.9 \text { kg } \\
\text { Outer dia.: } 40 \mathrm{~mm}\end{array}$ \\
\hline
\end{tabular}

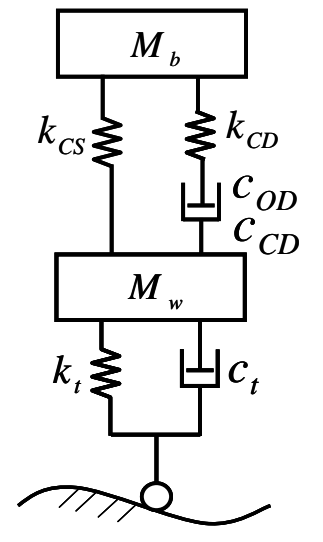

Fig. 2 Suspension model

Table 4 Characteristics of the evaluated suspensions (mass, spring constants and damping coefficients)

\begin{tabular}{|l|c|c|}
\hline \multicolumn{1}{|c|}{ Parameter } & Frontal suspension & Rear suspension \\
\hline Body mass, $M_{b}[\mathrm{~kg}]$ & 240 & 240 \\
\hline Wheel mass, $M_{w}[\mathrm{~kg}]$ & 27 & 23 \\
\hline Constant of the compression helical spring, $k_{C S}[\mathrm{~N} / \mathrm{mm}]$ & 21.6 & 18.6 \\
\hline Spring constant of the colloidal damper, $k_{C D}[\mathrm{~N} / \mathrm{mm}]$ & 35 & 25 \\
\hline Damping coefficient of the oil damper, $c_{O D}[\mathrm{Ns} / \mathrm{m}]$ & 730 & 675 \\
\hline Damping coefficient of the colloidal damper, $c_{C D}[\mathrm{Ns} / \mathrm{m}]$ & 1,450 & 735 \\
\hline Damping coefficient of the tire, $c_{t}[\mathrm{Ns} / \mathrm{m}]$ & 81 & 81 \\
\hline
\end{tabular}

Table 5 Variation of the tire spring constant versus the inflation pressure

\begin{tabular}{|c|l|l|l|l|l|}
\hline Inflation pressure $[\mathrm{kPa}]$ & 150 & 175 & 200 & 225 & 250 \\
\hline Tire spring constant, $k_{t}[\mathrm{~N} / \mathrm{mm}]$ & 195 & 205 & 215 & 225 & 235 \\
\hline
\end{tabular}

\section{4. 自動車のインパルス実験による快適性評価}

自動車の快適性を評価するために下記のような振動測定・解析方法を用いた。凹凸路面として，一つのアスフ アルトの半正弦波段差（高さ：37 mm，幅 b : $405 \mathrm{~mm}$ ) を持つ一般道路を使用した. GPS スピードメータを用い て自動車の走行速度 $V$ を 5 40 km/h の範囲内で変動させ, $2.5 \mathrm{~km} / \mathrm{h}$ の刻みで車速を調整した. ある速度で自動車 がアスファルト段差を通過した際に発生する衝撃（インパルスのような励振）によって自動車の加振を得て，規 格で定められた箇所の振動を加速度計で測定し, 車両の快適性を評価した (図 3, 図 4 参照). また, 自動車停止 
時にもエンジンの励振による得られた振動を加速度計で計測し，停止状態で車両の快適性を評価した．実験時に タイヤの空気圧力を $150,175,200 ， 225$, 並びに $250 \mathrm{kPa}$ とした.

乗心地ファクタによる自動車の快適性の評価方法では，車両の速度を記録しながら 5 箇所（左前輪懸架装置の 上下，右後輪懸架装置の上下，並びに座席）に設置した 1 軸（縦方向）の加速度計で加速度を測定し，アンプで 信号を増幅し，モバイルレコーダでアナログ信号をデジタル信号に変換した後，ノートパソコンに入力し，振動 解析による等価加速度 $a_{K}$ を計算する (図 3 参照)。これに対して, ISO 2631 規格で定められた自動車の快適性の 評価方法では，車両の速度を記録しながら 3 箇所（足支持面，座席，並びに背もたれ面）に設置した 3 軸（ $x, y, z$ 方向）の加速度計により得られた振動の信号を乗心地測定装置（ディシーインスツルメンツ株式会社で開発され た快適性の評価システム）で収録し，振動解析による等価加速度 $a_{W}$ を計算する (図 4 参照).

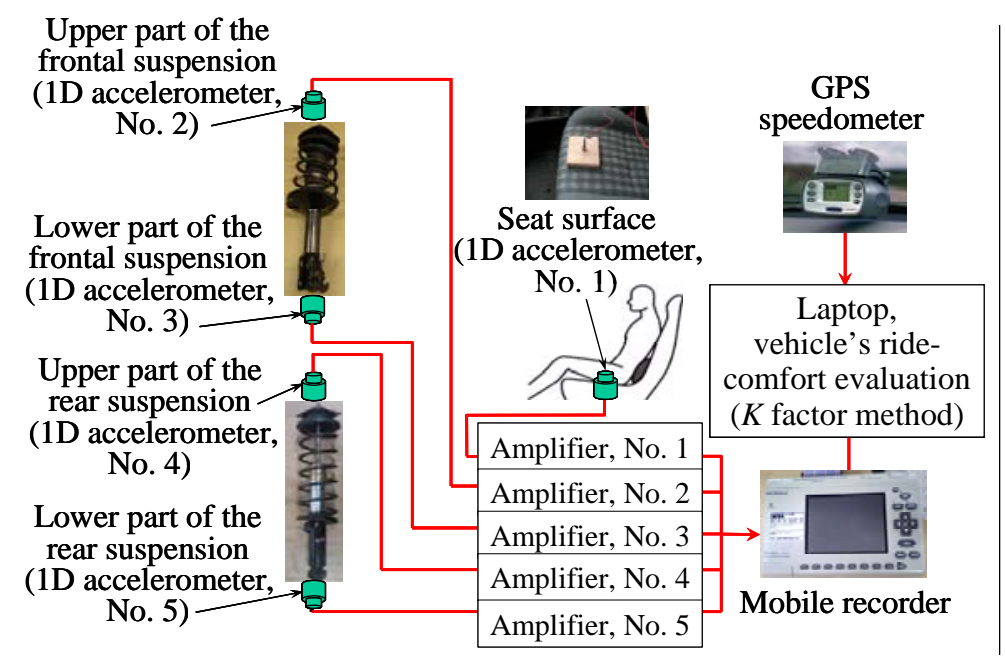

Fig. 3 Vibration measurement equipment to evaluate the vehicle's ride-comfort ( $K$ factor method)

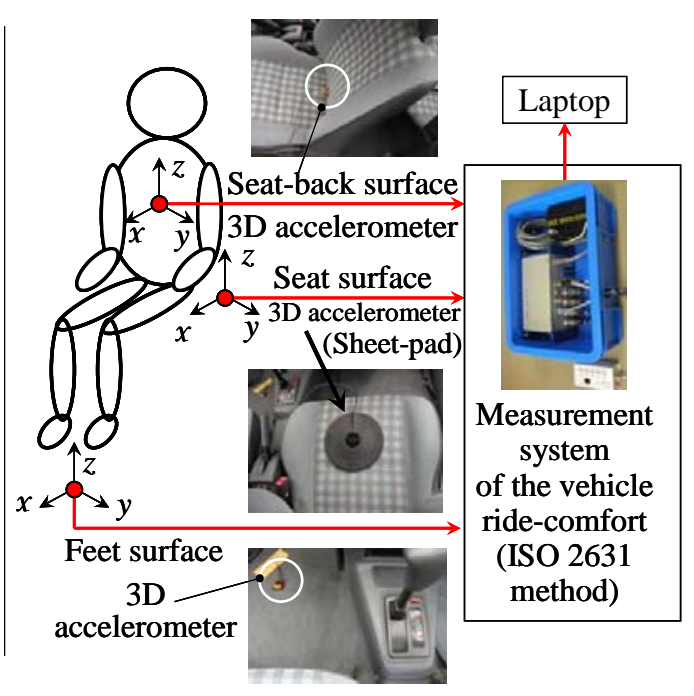

Fig. 4 Vibration measurement equipment to evaluate the vehicle's ride-comfort (ISO 2631 method)

\section{5. 実験結果及び考察}

最初に自動車の左右前後輪に油圧ダンパーと圧縮コイルばねとの並列構造からなる従来の懸架装置を設置し, インパルス実験による車両の基準快適性データを調べた。基準結果として, 図 5 に乗心地ファクタ法で定められ た等価加速度 $a_{K}$, 図 6 に ISO 2631 規格で定められた等価加速度 $a_{W}$ と自動車の走行速度との関係を示す.

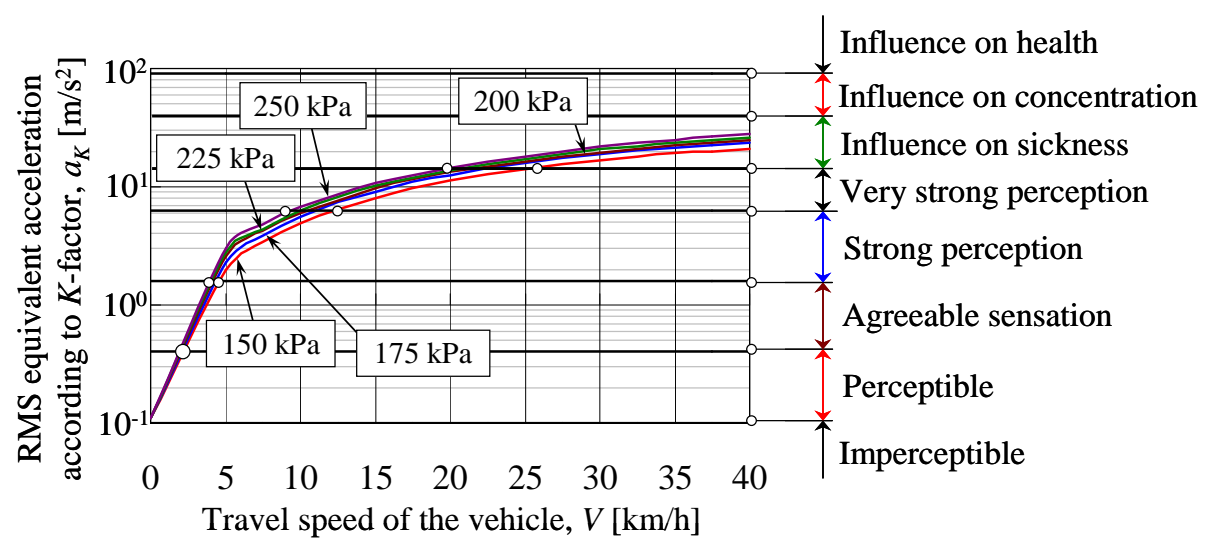

Fig. 5 Variation of the RMS equivalent acceleration ( $K$ factor method) versus the travel speed of a vehicle equipped at frontal and rear suspensions with oil dampers mounted in parallel with compression springs, for various values of the inflation pressure 


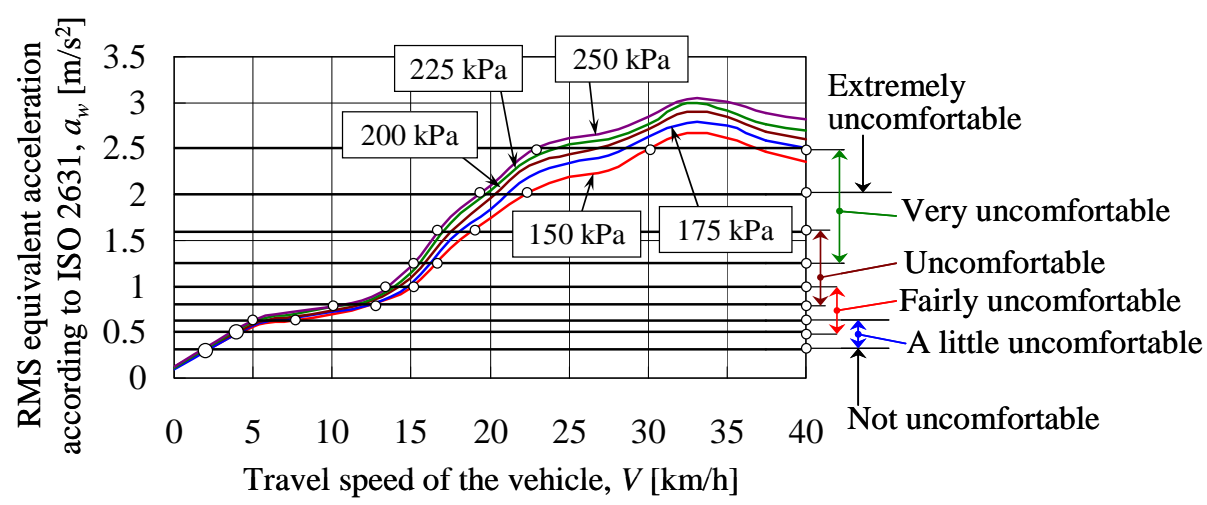

Fig. 6 Variation of the RMS equivalent acceleration (ISO 2631 method) versus the travel speed of a vehicle equipped at frontal and rear suspensions with oil dampers mounted in parallel with compression springs, for various values of the inflation pressure

図 5, 6 より, 車両の走行速度の増加，またはタイヤの空気圧力の増加と共に等価加速度が増加する，つまり， 車の快適性が悪くなることが分かる，これは，車両の走行速度 $V$ が増加すると，凹凸路面の励振によって得られ た周波数（ $f=V / \lambda, \lambda$ は凹凸路面の波長である.） は増加し, 懸架装置の固有振動数值の付近（共振状態）に なる. 逆に, 固有振動数 $f_{n}$ に対応する速度 $V_{n}=\lambda f_{n}$ を超えて車速が増加すると, 等価加速度が減少する.また, タイヤの空気圧力が増加すると, タイヤが硬くなるので, 岡性タイヤによって車両の乗心地が悪くなると考えら れる. 図 5, 6 の右側に表 1,2 に合わせた人間の振動知覚力の範囲を指示する. すると, 等価加速度值 $a_{K}$ と $a_{W}$ が 異なっても車速と人間の受振感範囲との関係が明らかとなり, 乗心地ファクタ法と ISO 2631 規格により得られた 快適性程度を間接的に比較できる. その結果, 走行速度は $0 \leq V \leq 2 \mathrm{~km} / \mathrm{h}$ となると, 人間が振動を少し知覚して いる（perceptible, $K$ factor 法）・不快な感じではない（not uncomfortable, ISO 2631 法)，走行速度は $2 \leq V \leq 4 \mathrm{~km} / \mathrm{h}$ となると, 人間が振動を快く感じる (agreeable sensation, $K$ factor 法)・少し不快な感じである (a little uncomfortable, ISO 2631 法), 走行速度は $V \leq 9 \sim 13 \mathrm{~km} / \mathrm{h}$ となると, 人間が振動を強く感じる (strong perception, $K$ factor 法), 走行 速度は $V \leq 13 \sim 15 \mathrm{~km} / \mathrm{h}$ となると, やや不快な感じである (fairly uncomfortable, ISO 2631 法), 走行速度はV $\leq 20$ 26 $\mathrm{km} / \mathrm{h}$ となると，人間が振動を非常に強く感じる（very strong perception, $K$ factor 法)，並びに走行速度は $V \leq 23 \sim 30$ $\mathrm{km} / \mathrm{h}$ となると, 非常に不快な感じである（very uncomfortable, ISO 2631 法). 従って, 走行速度の増加と共に乗心 地ファクタ法と ISO 2631 法で得られた車両の快適性範囲が一致していると言える. また, 20 26 km/h の走行速度 を超えると，振動が人間の気分に影響を及ぼす（influence on sickness, $K$ factor 法）状況となる.つまり，本インパ ルス実験では $40 \mathrm{~km} / \mathrm{h}$ の最大車速が高すぎたが，人間の能率・健康状態に影響を及ぼすことはなかったと考えら れる. さらに，この基準結果に基づいて車の快適性評価に関する信頼性を高めることができたと言える.

最近，トヨタ自動車ではコロイダル䀣架装置において 4 輪のV8 4.3L の乗用車を用いた実路走行実験（車速： $80 \mathrm{~km} / \mathrm{h}$ ) による乗心地が評価された(16). 古典的な懸架装置の場合, 固有振動数は $f_{n}=1.2 \mathrm{~Hz}$, ばね定数は $36.1 \mathrm{~N} / \mathrm{mm}$, 並びに減衰係数は $1,120 \mathrm{Ns} / \mathrm{m}$ であったのに対して，コロイダル懸架装置の場合，固有振動数は $f_{n}=2.8 \mathrm{~Hz}$, ばね 定数は $213.2 \mathrm{~N} / \mathrm{mm}$, 並びに減衰係数は $1,742 \mathrm{Ns} / \mathrm{m}$ であった.コロイダル懸架装置に関する試作・評価した結果, 車高保持，ばね定数及び減衰係数の基本特性を持ち，サスペンションの技術として可能であることが確認され た. しかし, 現時点の性能面の課題は, コロイダル懸架装置を用いた車両の乗心地特性を改善するためにコロイ ダルダンパーのばね定数を減少しなければならない，といった対策が提案された ${ }^{(16)}$. 本研究においては，参考文 献 ${ }^{(16)}$ に発表された車体の PSD 加速度グラフを表化し (表 6 参照), 乗心地ファクタ法による等価加速度 $a_{K}$, 並び に ISO 2631 法による等価加速度 $a_{W}$ を計算した. その結果, 古典的な眯架装置の場合は $a_{K}=10.1 \mathrm{~m} / \mathrm{s}^{2}$ (人間が振動 を非常に強く感じる, very strong perception), 並びに $a_{W}=0.8 \mathrm{~m} / \mathrm{s}^{2}$ (やや不快な感じである, fairly uncomfortable) となり，コロイダル懸架装置の場合は $a_{K}=27.8 \mathrm{~m} / \mathrm{s}^{2}$ (振動が人間の気分に影響を及ぼす, influence on sickness), 並びに $a_{W}=2.1 \mathrm{~m} / \mathrm{s}^{2}$ (非常に不快な感じである, very uncomfortable) となる. 従って, 古典的な懸架装置の変わり にコロイダル眯架装置を用いた場合はコロイダルばね定数が 6 倍高すぎたので, 車両の快適性は乗心地ファクタ の基準によれば, 1 ランク，ISO 2631 の基準によれば，2ランク下がってしまったと考えられる. 
Table 6 Values of the PSD body acceleration versus frequency for classical and colloidal suspensions (Tabulated data after Ref. ${ }^{(16)}$ )

\begin{tabular}{|l|c|c|c|c|c|c|c|c|c|c|}
\hline Frequency, $f[\mathrm{~Hz}$ ] & 0.100 & 0.125 & 0.160 & 0.200 & 0.250 & 0.315 & 0.400 & 0.500 & 0.630 & 0.800 \\
\hline PSD acc., [dB]; Classical suspension & -23.8 & -22.6 & -20.0 & -18.5 & -16.0 & -14.0 & -12.3 & -10.3 & -8.4 & -6.0 \\
\hline PSD acc., [dB]; Colloidal suspension & -24.3 & -23.1 & -20.5 & -19.2 & -17.0 & -15.2 & -13.7 & -11.5 & -10.4 & -9.0 \\
\hline Frequency, $f[\mathrm{~Hz}$ ] & 1.00 & 1.25 & 1.60 & 2.00 & 2.50 & 3.15 & 4.00 & 5.00 & 6.30 & 8.00 \\
\hline PSD acc., [dB]; Classical suspension & -4.5 & -4.4 & -6.4 & -9.0 & -9.6 & -11.0 & -13.5 & -14.5 & -14.0 & -13.5 \\
\hline PSD acc., [dB]; Colloidal suspension & -7.5 & -3.9 & 2.3 & 2.0 & 5.6 & 2.5 & -4.3 & -8.0 & -9.6 & -11.3 \\
\hline Frequency, $f$ [Hz] & 10.0 & 12.5 & 16.0 & 20.0 & 25.0 & 31.5 & 40.0 & 50.0 & 63.0 & 80.0 \\
\hline PSD acc., [dB]; Classical suspension & -17.0 & -20.0 & -21.5 & -23.6 & -25.5 & -27.9 & -29.5 & -31.5 & -33.7 & -36.6 \\
\hline PSD acc., [dB]; Colloidal suspension & -14.3 & -20.0 & -22.4 & -25.1 & -27.6 & -31.0 & -33.5 & -36.2 & -39.0 & -42.7 \\
\hline
\end{tabular}

本研究では，乗心地特性において古典的な懸架装置とコロイダル䁻架装置の比較を深めるために，図 7 にタイ ヤの空気圧力を $200 \mathrm{kPa}$ とし, 前後輪懸架装置の組合せとして, (1)前輪 : 油圧ダンパーと圧縮コイルばね・後輪 : 油圧ダンパーと圧縮コイルばね (赤線), (2)前輪 : 油圧ダンパーと圧縮コイルばね・後輪 : コロイダルダンパーと 圧縮コイルばね (青線)，(3)前輪：コロイダルダンパーと圧縮コイルばね・後輪：油圧ダンパーと圧縮コイルばね (茶色の線)，並びに(4)前輪 : 圧縮コイルばねを省いたコロイダル懸架装置・後輪 : 油圧ダンパーと圧縮コイルば ね (緑線) としたときの等価加速度 $a_{W}$ と自動車の走行速度との関係を示す. 図 7 より, 以前の結果 ${ }^{(16)}$ と同様にコ ロイダル懸架装置を設置した場合，特に前輪にコロイダル懸架装置を設置した場合，車両の快適性が悪くなると 見られる.また，前輪に古典的な懸架装置を用いた場合は，高速範囲でグラフの一つのピークが得られるのに対 して，前輪にコロイダル懸架装置を設置した場合は，高速範囲と同時に低速範囲でもグラフのピークが発生して いることが分かる. この特徵を説明するために, 自動車のインパルス励振（図 8 参照）と, 等価加速度 $a_{W}$ の計算 に使用する主フィルタ $W_{k}$ (図 9 参照) について考慮する.

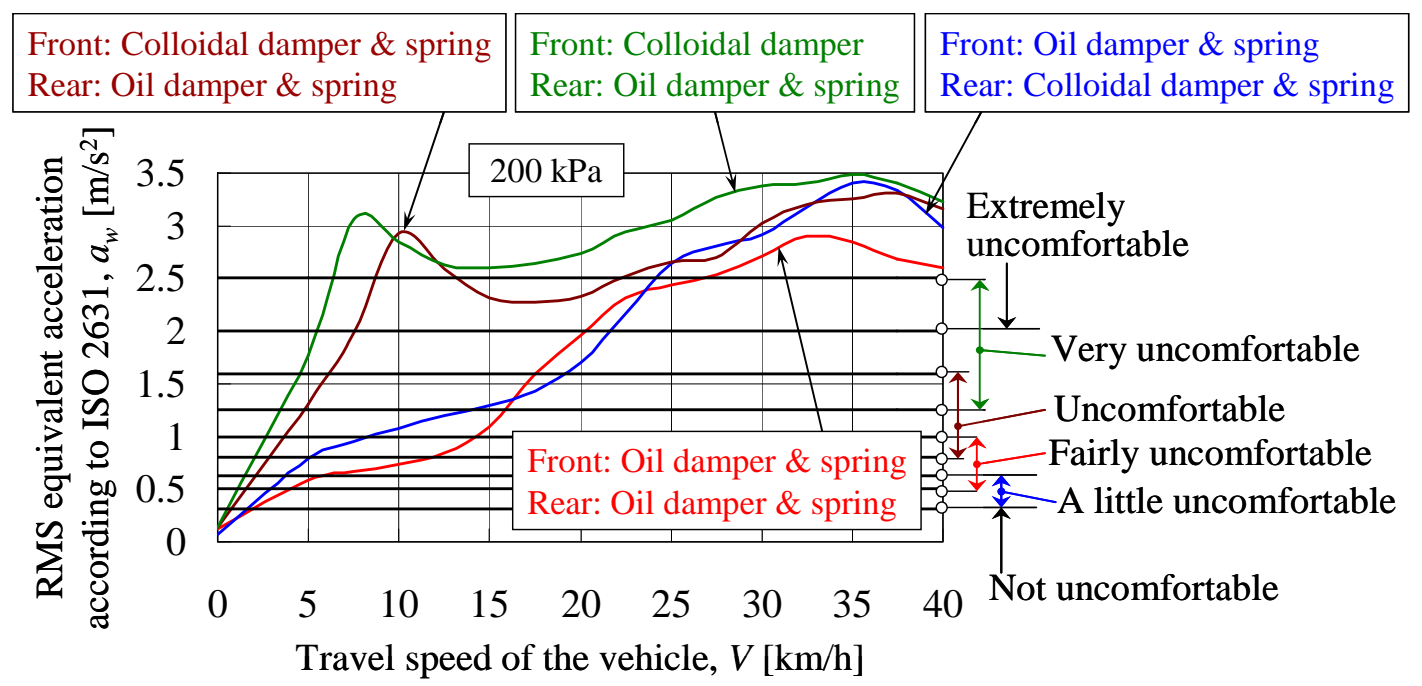

Fig. 7 Variation of the RMS equivalent acceleration (ISO 2631 method) versus the travel speed of a vehicle equipped with various types of frontal and rear suspensions, for an inflation pressure of $200 \mathrm{kPa}$

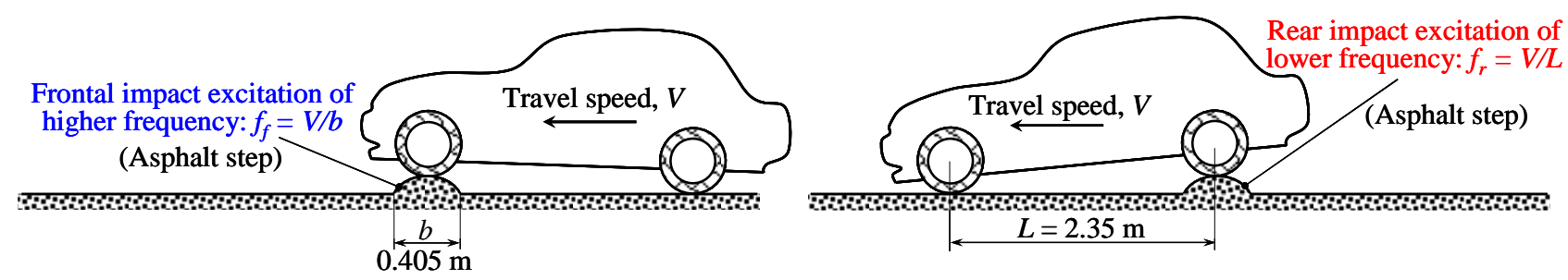

Fig. 8 Frontal impact excitation of higher frequency and rear impact excitation of lower frequency of the tested autovehicle 


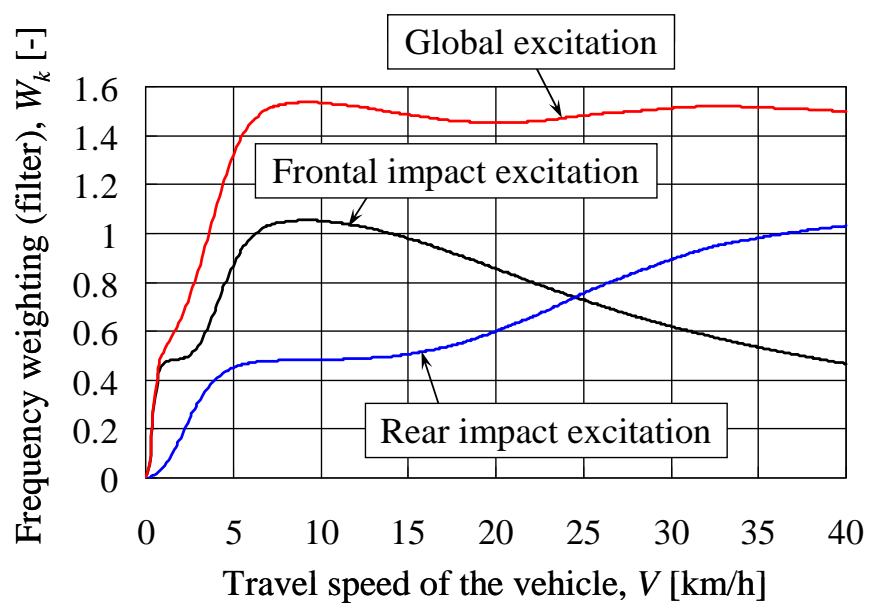

Fig. 9 Variation of the main frequency weighting $W_{k}$, used by the ISO 2631 method for ride-comfort evaluation, versus travel speed of an autovehicle subjected to frontal and rear impact excitations

自動車の走行実験では，最初にアスファルト段差により前輪懸架装置が衝撃を受けて，段差の幅 $b$ によって高

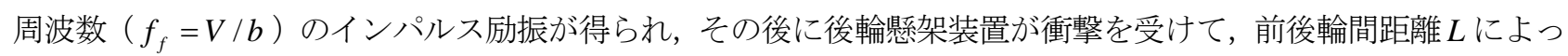
て低周波数 $\left(f_{r}=V / L\right)$ のインパルス励振が得られる. そこで, 図 9 に前輪インパルス励振, 後輪インパルス励 振, 並びに総和インパルス励振によりフィルタ $W_{k}$ の走行速度依存性を示寸. 具体的に, 図 1 の横軸は周波数 $f$ で あったのに対して, 図 9 の横軸は走行速度 $V=f \lambda （ \lambda$ は凹凸路面の波長である.）となる. 前輪インパルス励振 の場合 $(\lambda=b)$, フィルタ $W_{k}$ のピークが走行速度範囲の内側に発生するが, 後輪インパルス励振の場合 $(\lambda=L)$, フィルタ $W_{k}$ のピークが $40 \mathrm{~km} / \mathrm{h}$ を超えて見えない箇所（走行速度範囲の外側）に発生することが分かる. 総和イ ンパルス励振の場合，低速範囲と同時に高速範囲でもグラフのピークが発生していることが分かる. そこで，図 7 と図 9 の比較より, 懸架装置の組合せ(1)と（2)，つまり，前輪に古典的な懸架装置を用いた場合は主に後輪イン パルス励振に対応する応答が見られ，懸架装置の組合せ(3)と(4)，つまり，前輪にコロイダル懸架装置を使用した 場合は総和インパルス励振に対応寸る応答が得られたと考えられる.

\section{6. コロイダル䯚架装置の最適ばね定数}

コロイダル懸架装置を用いた車両の乗心地を改善するために, 最適剛性比, つまり, コロイダルばね定数 $k_{C D}$ と 圧縮ばね将数 $k_{C S}$ との最適比について調べた ${ }^{(21)}$ ，その際，図 2 の下部に発生するタイヤ共振を無視した近似モデ ルで考え, 図 2 の上部に発生する車体共振と関係した圧縮コイルばね（弾性要素）にコロイダルダンパー（マク スウェル要素）を並列に取り付けたシリアル・パラレルモデルを使用し，懸架装置の振動伝達率を検討した ${ }^{(21)}$. その結果, 剛性比 $k_{C D} / k_{C S}$ が高くなるにつれて, 車体共振ピークが小さくなっていくが, 高周波数域では振動伝 達率が大きくなっていくことが分かった，そこで，車両の乗心地を極大化するために，全周波数範囲で振動伝達 率を周波数で積分し, 振動伝達率のグラフ下の面積を得た. このような振動伝達率のグラフ下の面積と剛性比と の関係グラフは, 谷のような曲線（四曲線）となった. このグラフの極小值は振動伝達率の極小值，つまり，乗 心地の極大值を示しているため, このときの剛性比が最適となる. フィルタを掛けない場合, 最適剛性比 : $\left(k_{C D} / k_{C S}\right)_{o p t}=1$, フィルタ $G$ (乗心地ファクタ法) を掛けた場合, 最適剛性比 : $\left(k_{C D} / k_{C S}\right)_{o p t}=0.5$, 並びにフィ ルタ $W_{k}$ (ISO 2631 法) を掛けた場合, 最適剛性比 : $\left(k_{C D} / k_{C S}\right)_{o p t}=0.6$, といった最適剛性比を決定することがで きた ${ }^{(21)}$. 今後の課題として, このような最適剛性比を用いたコロイダル懸架装置の再試作では車両の乗心地を調 ベたい. 


\section{7. 結語}

本研究では安価な実験方法として，アスファルト段差を持つ路面でのコロイダル懸架装置を用いた自動車の走 行実験を行い, 段差を通過した際に発生するインパルス応答より乗心地ファクタ法の等価加速度, 並びに ISO 2631 規格で定められた等価（合成補正）加速度を計算し，車両の快適性を評価した．その結果，走行速度の増加と共 に乗心地ファクタ法と ISO 2631 法で得られた車両の快適性範囲が一致していった. また，古典的な懸架装置の変 わりにコロイダル懸架装置を用いた場合はコロイダルばね定数が高すぎたので，車両の快適性は乗心地ファクタ の基準によれば，1 ランク，ISO 2631 の基準によれば，2 ランク下がってしまった.さらに，前輪に古典的な懸 架装置を用いた場合は主に後輪インパルス励振に対応する応答が見られ，前輪にコロイダル懸架装置を使用した 場合は前後の総和インパルス励振に対応する応答が得られた．コロイダル懸架装置を用いた車両の乗心地を改善 するために，振動解析に基づいて対策方法を提案した.

\section{謝 辞}

本研究には科学研究費補助金（基盤研究 (C) ) ・課題番号 22560151 の助成金をいただいたことに感謝いたしま す. 本研究に当たり，自動車の快適性評価において技術アドバイスをして頂いたディシーインスツルメンツ株式 会社の北川登章様，並びに水上計測株式会社の高橋繁光様には深く感謝の意を表します.

\section{文献}

(1) Eroshenko, V.A., "A New Paradigm of Mechanical Energy Dissipation; Part 1: Theoretical Aspects and Practical Solutions", Journal of Automobile Engineering, Vol. 221 (2007), pp. 285-300.

(2) Eroshenko, V.A., Piatiletov, I., Coiffard, L., and Stoudenets, V., "A New Paradigm of Mechanical Energy Dissipation; Part 2: Experimental Investigation and Effectiveness of a Novel Car Damper”, Journal of Automobile Engineering, Vol. 221 (2007), pp. 301-312.

(3) Suciu, C.V., Iwatsubo, T., and Deki, S., "Investigation of a Colloidal Damper", Journal of Colloid and Interface Science, Vol. 259 (2003), pp. 62-80.

(4) Suciu, C.V., Iwatsubo, T., and Deki, S., "Novel Principle of Mechanical Energy Dissipation; Part 1: Static Performances of Colloidal Damper”, JSME International Journal, Vol. C47 (2004), pp. 180-188.

(5) Suciu, C.V., and Iwatsubo, T., "Novel Principle of Mechanical Energy Dissipation; Part 2: Dynamic Performances of Colloidal Damper”, JSME International Journal, Vol. C47 (2004), pp. 189-198.

(6) Suciu, C.V., Iwatsubo, T., Yaguchi, K., and Ikenaga, M., "Novel and Global Approach of the Complex and Interconnected Phenomena Related to the Contact Line Movement Past a Solid Surface from Hydrophobized Silica Gel”, Journal of Colloid and Interface Science, Vol. 283 (2005), pp. 196-214.

(7) Iwatsubo, T., Suciu, C.V., Ikenaga, M., and Yaguchi, K., "Dynamic Characteristics of a New Damping Element Based on Surface Extension Principle in Nanopores”, Journal of Sound and Vibration, Vol. 308 (2007), pp. 579-590.

(8) Suciu, C.V., and Yaguchi, K., "Endurance Tests on a Colloidal Damper Destined to Vehicle Suspension", Experimental Mechanics an International Journal, Vol. 49 (2009), pp. 383-393.

(9) Suciu, C.V., Tani, S., and Yaguchi, K., "On the Fatigue Fracture at Adsorption/Desorption of Water in/from Liquid-Repellent Nanoporous Silica”, Acta Mechanica, Vol. 214 (2010), pp. 195-203.

(10) Suciu, C.V, 谷真悟, 三好健太, “コロイダルダンパーの熱特性に関する実験的研究”, 日本機械学会論文集 C 編, Vol. 76, No. 765 (2010), pp. 1043-1049.

(11) Suciu, C.V., Tani, S., and Miyoshi, K., "Experimental Study on the Thermal Characteristics of a Colloidal Damper”, JSME, Journal of System Design and Dynamics, Vol. 4, No. 6 (2010), pp. 899-913.

(12) Iwatsubo, T., Washio, K., Yano, H., and Miyazaki, M., “Experimental Study of a Colloidal Damper to Practical Application”, JSME, Journal of System Design and Dynamics, Vol. 2, No. 5 (2008), pp. 1160-1169. 
(13) Suciu, C.V, 井崎宏史，森崎大介，野中隆広，“圧縮コイルばね有無を用いた自動車の懸架装置用コロイダルダンパ 一に関する実験的研究”, 日本機械学会 D\&D2009, CD-ROM (2009), pp. 1-6.

(14) Suciu, C.V., "Experimental Study on the Frontal Suspension of an Automobile Equipped with Colloidal Dampers", Proceedings of APVC2009, New Zealand, CD-ROM (2009), pp. 1-10.

(15) Suciu, C.V., "Ride-Comfort of an Automobile Equipped with Colloidal Dampers at its Frontal Suspensions", Proceedings of ISMA2010, Belgium, CD-ROM (2010), pp. 4233-4245.

(16) 武馬修一, “表面張力を応用したコロイダルシリンダの車両用サスペンションとしての可能性検討”, 自動車技術会 春季大会学術講演会前刷集 No. 2-11 (2011), pp. 13-18.

(17) Lauwerys, C., Swevers, J, and Sas, P., “Linear Control of Car Suspension using Nonlinear Actuator Control”, Proceedings of ISMA2002, Belgium, Vol. I (2002), pp. 55-61.

(18) Vaes, D., Swevers, J, and Sas, P., "Experimental Multivariable Tracking Control on an Automotive Vibration Test Rig", Proceedings of ISMA2004, Belgium, CD-ROM (2004), pp. 311-323.

(19) “Mechanical Vibration and Shock - Evaluation of Human Exposure to Whole-Body Vibration; Part 1: General Requirements", International Organization for Standardization, ISO 2631-1 (1997), pp. 1-27.

（20）駒村清二, 渡辺烈夫, 水向建, 溝淵利博, 森田雄二, 政村辰也, 荒井順一, 松本洋, 辻亘, 松田久志, 可児旭, 小 野八束，辻文彦，吉田昇，“自動車のサスペンション”，カヤバ工業株式会社編，第二版，山海堂 (2005), pp. 1-114.

(21) Suciu, C.V., and Tobiishi, T., "Investigations on the Optimum Design of a Colloidal Damper for Autovehicle Suspension”, Proceedings of WCSMO-9, Japan, CD-ROM (2011), pp. 1-10. 